\title{
Tropical Soda Apple: A Noxious Weed in Florida1
}

\author{
J. Jeffrey Mullahey, Jason Ferrell, and Brent Sellers ${ }^{2}$
}

Tropical soda apple (Solanum viarum Dunal) is a perennial weed that creates serious problems in many perennial grass pastures and native areas of Florida (Figure 1). This noxious weed, having foliage unpalatable to livestock and highly viable seed, can infest a pasture or native area within 1 to 2 years, resulting in lower stocking rates (animals per acre). The incidence of this plant has been highest in Florida, though the weed is present in Georgia, Alabama, Mississippi, South Carolina, Tennessee, Louisiana, and Pennsylvania. Within Florida, the incidence of this plant has been highest in the south, although it is now distributed throughout the entire state.

\section{Plant Description}

At maturity, TSA is 3 to 6 feet tall and the entire plant, including stems and leaves, has thorn-like prickles approximately 0.5 to 1 inch long (Figure 2). Leaves are pubescent (hairy), measure 6 to 8 inches long and 3 to 6 inches wide, and are lobed (Figure 3). The flowers are white with yellow stamens. The globular fruit, approximately 1 inch in diameter, is

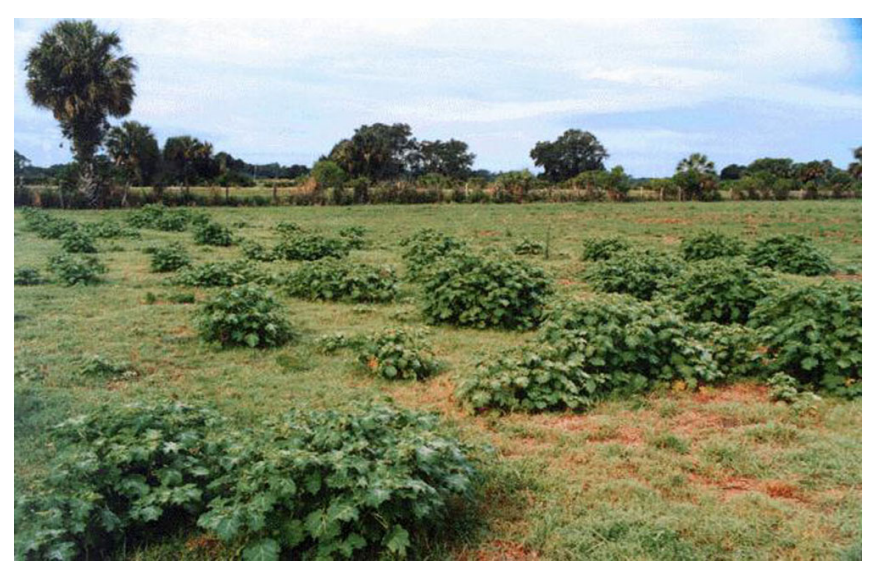

Figure 1. Tropical soda apple in a typical south Florida bahiagrass pasture.

yellow when mature (Figure 4). Each mature fruit contains about 400 light red-brown seeds with diameters of approximately 0.10 inch. Seeds are only moderately flattened and are found in a mucilaginous layer containing a glycoalkaloid called solasodine. TSA fruit collected in south Florida averaged 1 inch in diameter, with an average of 413 seeds per fruit.

1. This document is SS-AGR-77, one of a series of the Agronomy Department, Florida Cooperative Extension Service, Institute of Food and Agricultural Sciences, University of Florida. Published October 1993 as WEC-7. Revised: August 2006. Reviewed: November 2006. Visit the EDIS Web Site at http://edis.ifas.ufl.edu.

2. J. Jeffrey Mullahey, professor and center director, West Florida Research and Education Center--Milton, FL; Jason Ferrell, assistant professor, Agronomy Department; Brent Sellers, assistant professor, Range Cattle Research and Education Center--Ona, FL; Florida Cooperative Extension Service, Institute of Food and Agricultural Sciences, University of Florida, Gainesville, FL.

The use of trade names in this publication is solely for the purpose of providing specific information. UF/IFAS does not guarantee or warranty the products named, and references to them in this publication does not signify our approval to the exclusion of other products of suitable composition. All chemicals should be used in accordance with directions on the manufacturer's label.

The Institute of Food and Agricultural Sciences (IFAS) is an Equal Opportunity Institution authorized to provide research, educational information and other services only to individuals and institutions that function with non-discrimination with respect to race, creed, color, religion, age, disability, sex, sexual orientation, marital status, national origin, political opinions or affiliations. U.S. Department of Agriculture, Cooperative Extension Service, University of Florida, IFAS, Florida A. \& M. University Cooperative Extension Program, and Boards of County Commissioners Cooperating. Larry Arrington, Dean 


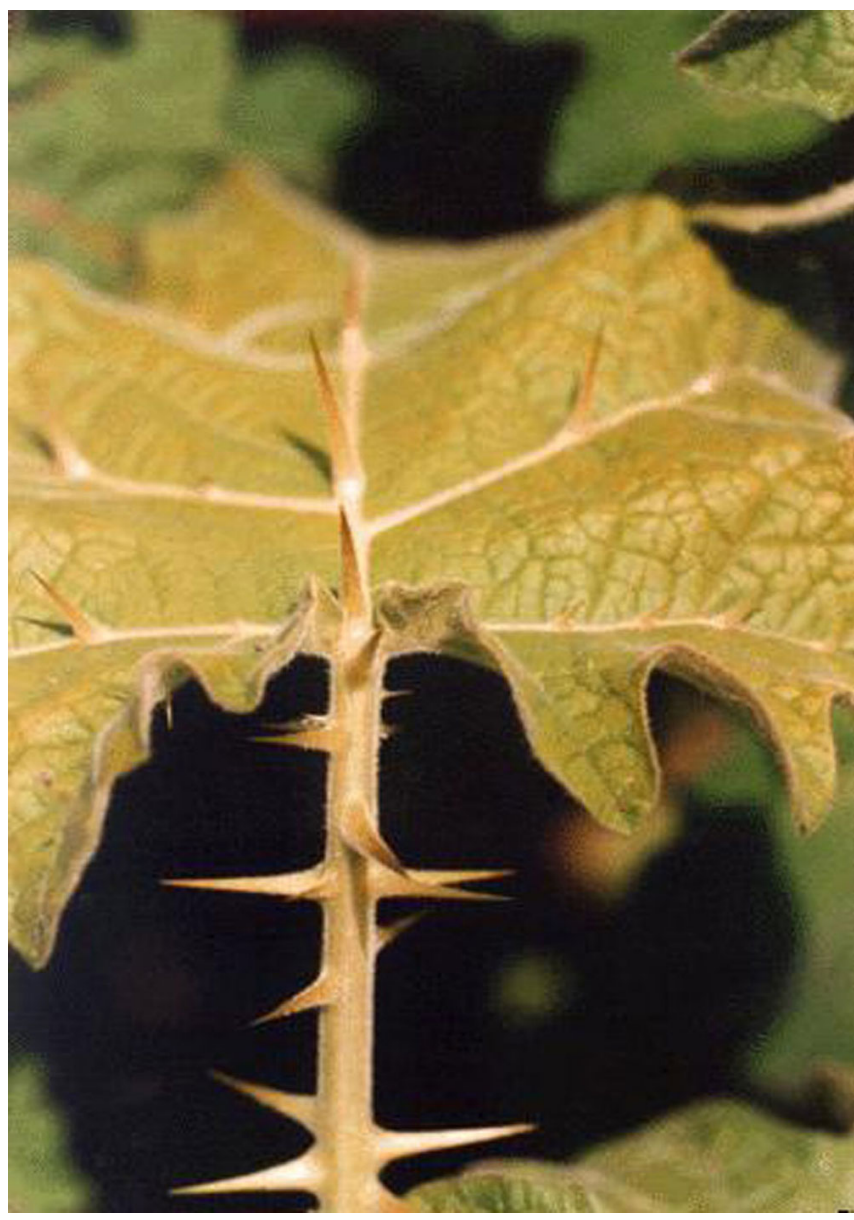

Figure 2. Thorn-like prickles on a tropical soda apple leaf.

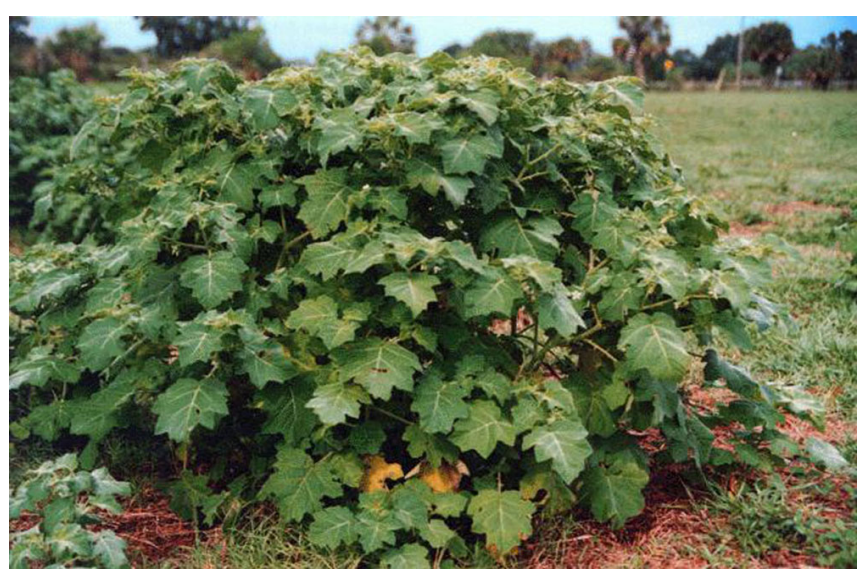

Figure 3. Mature tropical soda apple plant.

\section{Weed Biology}

Although TSA flowers throughout the year, flowering is concentrated from September through May. Fruit production occurs throughout the year (primarily from September through May), ensuring large numbers of viable seeds (from 40,000 to 50,000 per plant at $75 \%$ germination) for seed dispersal. Seed in the top 1 to 2 inches of the soil surface is more

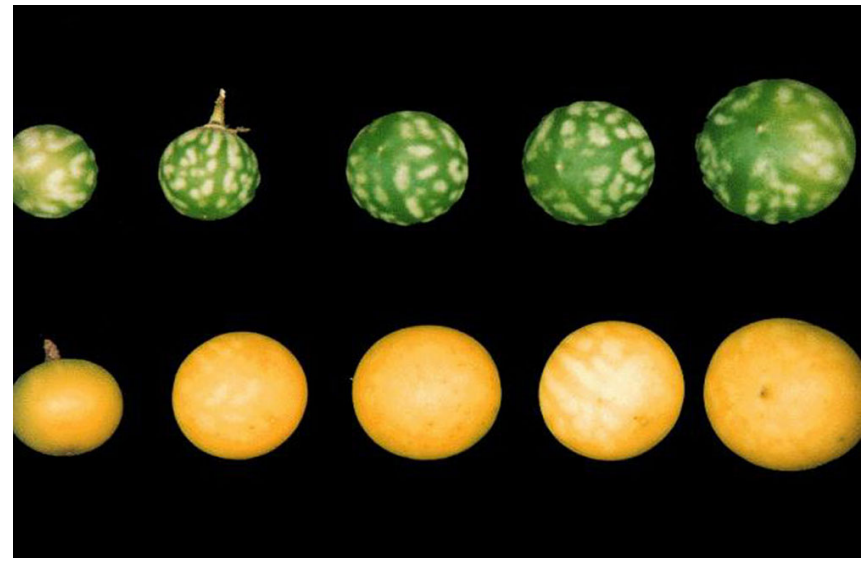

Figure 4. Tropical soda apple fruit. Top row: immature fruit. Bottom row: mature fruit.

likely to germinate than seed on the soil surface or seed placed at a depth greater than 3 inches. White (immature) seed is not viable, regardless of fruit color. Livestock and wildlife such as feral hogs, deer, and raccoons eat the fruit and disperse the seed via feces, spreading the plant to other land areas.

Seedling emergence has been observed primarily during the dry season (October through May). New plants can emerge either from seeds or from roots of existing plants, whose buds regenerate new shoots. The root system can be extensive, with feeder roots a few inches below ground measuring 0.25 to 1.0 inch in diameter and extending 3 to 6 feet horizontally from the crown of the plant.

\section{Weed Ecology}

TSA has been observed as a weed in pastures, ditch banks, sod fields, citrus groves, sugar cane fields, vegetable fields, roadsides, rangeland, and nature preserves. It is a common weed in South America, India, the West Indies, Honduras, and Mexico. Native to Argentina and central Brazil, TSA has been introduced in Africa, much of India, and Nepal and can be expected to occur in other subtropical areas. How TSA was introduced into Florida is not known. In Florida, it is an obligate weed mainly associated with human activities.

Tropical soda apple is less productive, or may actually die, in the summer, when water accumulates in fields. Solanum spp. were first reported by ranchers in south Florida in the early 1960s. According to these initial reports, however, the fruit color was 
cherry red, not yellow. Apparently, ranchers were observing Solanum capsicoides, not TSA. For the past 10 years in south Florida, TSA has been the more prevalent of the two species. Although the reasons for TSA's rapid increase are not well understood, its seed is spread by animals, contaminated hay, and grass seed (e.g., that of bahiagrass).

\section{Weed Control}

\section{Dense Infestations}

Milestone and Forefront are the most effective herbicides for controlling dense stands of TSA. These herbicides possess postemergence control of existing plants and preemergence control of germinating seeds. Our research has shown that Milestone and Forefront will control germinating seedlings for over 6 months after application.

The application rate for Milestone is 5 to $7 \mathrm{oz} / \mathrm{A}$ while Forefront is 2 to $2.6 \mathrm{pt} / \mathrm{A}$. Although the lower application rates are highly effective on existing plants, the higher rates will provide more soil activity and are suggested if large amounts of TSA seed are present in the soil. Although mowing prior to herbicide application is not required, it is important to add a non-ionic surfactant $(0.25 \% \mathrm{v} / \mathrm{v})$ and apply in at least 20 gallons of water per acre.

Another option is to use Remedy herbicide. When using Remedy, mow plants to a 3-inch stubble height as soon as possible to keep plants from producing fruit and seed. Repeat mowing when plants reach the flowering stage (50-60 days) through April. Fifty to 60 days after the April mowing, when plant regrowth is at the first flower stage (late May - June), spray Remedy at $1 \mathrm{qt} / \mathrm{A}+0.25 \%$ nonionic surfactant in $40 \mathrm{gal} / \mathrm{A}$ of water.

Remedy does not possess soil residual and follow up applications to control escaped or new seedlings will be necessary.

Regardless which herbicide is used, regular scouting after treatment is necessary. TSA can produce fruit at almost any time during the growing season and give rise to hundreds of additional plants. It is important to monitor the fields to ensure that no plants are allowed to reestablish and produce fruit.

\section{Sparse infestations}

Areas with low TSA infestations should be targeted and each plant sprayed individually. Recommended herbicides for 95 to $100 \%$ control are as follows:

\section{Spot Application}

Milestone at 0.5 to $0.8 \mathrm{oz}$ per $2.5 \mathrm{gal}(15$ to $20 \mathrm{ml}$ per 2.5 gal. $)+0.25 \%$ nonionic surfactant + color marker. (Use a colored marker with the herbicide solution to avoid spraying the same plant twice, or not spraying a plant at all.)

Forefront or Remedy at $0.5 \%$ solution $(50 \mathrm{ml}$ per $2.5 \mathrm{gal})+0.25 \%$ nonionic surfactant + color marker.

Cover the entire TSA plant with spray to ensure herbicide uptake and maximum control. Allow herbicides to dry on plants 3-4 hours before rainfall. Monitor sprayed areas monthly and treat new TSA seedlings. Do not allow plants to produce fruit.

TSA control can also be achieved using dicamba at $1 \%+0.25 \%$ nonionic surfactant in $20-30$ gallons of water. Dicamba (Banvel, Clarity or Vanquish) is effective at controlling TSA, but the 2 quart rate is more expensive than other options. Be sure and follow the guidelines for spraying volatile herbicides such as dicamba and Remedy (see EDIS publication SS-AGR-12 Florida's Organo-Auxin Herbicide Rule [http://edis.ifas.ufl.edu/WG051] for more information).

\section{Shipping Cattle}

Ship cattle from an area that does not have TSA or is TSA fruit free. Mowing a TSA infested pasture prior to shipping will eliminate the fruit and the consumption of TSA seed by the cattle. The TSA seed can remain viable in the digestive tract for up to six days. Therefore, when you buy cattle, hold them in one area for up to six days to avoid the spread of TSA to other areas on your ranch. For more information, see EDIS publication SS-AGR-78 Shipping Cattle, Not Tropical Soda Apple Seed (http://edis.ifas.ufl.edu/UW187).

IFAS is researching methods to control TSA. Efforts to identify effective methods are focused on 
herbicide evaluations, herbicide rates, and biological control measures(insects and pathogens). IFAS is also conducting an aggressive TSA educational outreach program to educate ranchers and landowners. Individuals requiring additional information should contact their county Extension offices.

\section{Further Information}

\section{EDIS publications:}

SS-AGR-50 Tropical Soda Apple (Solanum viarum, Dunal) in Florida (http://edis.ifas.ufl.edu/WG201)

SS-AGR-78 Shipping Cattle, Not Tropical Soda Apple Seed (http://edis.ifas.ufl.edu/UW187)

SS-AGR-129 Tropical Soda Apple

Control--Sorting Through the Options

(http://edis.ifas.ufl.edu/AG261)

SS-AGR-130 Management Practices to Control Tropical Soda Apple

(http://edis.ifas.ufl.edu/UW188)

SS-AGR-131 Tropical Soda Apple Making a Comeback (http://edis.ifas.ufl.edu/UW189)

ENY-826 Biology of Gratiana boliviana, the First Biocontrol Agent Released to Control Tropical Soda Apple in the USA (http://edis.ifas.ufl.edu/IN487)

ENY-824 Classical Biological Control of Tropical Soda Apple in the USA (http://edis.ifas.ufl.edu/IN457)

\section{West Florida Research and Education Center:}

Tropical Soda Apple (http://tsa.ifas.ufl.edu/)

Tropical Soda Apple Best Management Practices--

North Florida

( http://tsa.ifas.ufl.edu/00Slides/NorthFlorida/ index.html)

\section{South Florida}

( http://tsa.ifas.ufl.edu/00Slides/SouthFlorida/ index.html) 